\title{
Informal Learning: Review of Research Perspectives in Polish and German Andragogy
}

\begin{abstract}
The aim of the article is to present selected themes that form part of the contemporary discourse on informal learning, which since the 1970s has dominated the scientific debate on learning, especially in the area of adult education. The authors, using Polish and German-language literature, outline areas of scientific and research interest, as well as tendencies in the contemporary approach to the learning processes of adolescents and adults. Moreover, they present exemplary results of research on informal learning, conducted within various fields: adult education, social pedagogy, economics and others. They indicate that separate treatment of human learning (division into formal, non-formal, and informal learning) is not always justified, and is not conducive to the analysis of learning processes.
\end{abstract}

\section{Keywords:}

informal learning, research on informal learning, lifelong learning, adult education, andragogy

\section{INTRODUCTION}

Through the centuries, the idea of adult learning has centered particularly around institutions, yet it was constantly accompanied by a belief that educational values are inherent in life itself, in people's everyday activities, in being with others, in

$1 \quad$ Faculty of Culture and Education, Warsaw University of Life Sciences, Poland. E-MAIL: ewa_przybylska@sggw.pl ORCID: 0000-0001-8338-5484

2 Department for Sociology of Education, Maria Grzegorzewska Academy of Special Education, Warsaw, Poland.

E-MAIL: blazej.przybylski@wp.pl ORCID: 0000-0002-0663-8692 
collectively drawing on and shaping culture. Already Aristotle drew attention to this, distinguishing between learning in everyday life, learning in specially-created institutions, formal instruction, and learning through experience (Andresen, Boud \& Cohen, 2000, p. 228; cited in: Rohs, 2016, p. 5). Optimism and faith in the redemptive power of formal education were extinguished in the late 1960s, during a time of economic stagnation, rising unemployment, as well as the unresolved issue of social inequalities in Western countries and problems mounting in Third World countries. It became clear that schools, universities, and other formal education institutions were unable to cope with the dynamic changes brought about by modern information and communication technologies. A growing demand for knowledge and qualifications in the era of modern communication and information technologies, and the emerging postulate of lifelong learning, have drawn the attention of researchers to learning processes taking place outside of the context of formal institutions.

In his 1968 publication titled “The World Education Crisis”, Philip H. Coombs, American educator, economist, and the acting director of the UNESCO Institute for Education Planning in Paris, suggested how to escape the dead end. In a separate chapter devoted to non-formal education he presented its values from the perspective of both highly industrialized countries and poor non-Western states with postcolonial traditions. His finding was that, compared to formal education, non-formal education has the ability to respond faster and more effectively to the demands of the world of work. In 1974, the World Bank publication "Attacking Rural Poverty” defined for the first time three areas of learning: formal, non-formal, and informal education (Coombs \& Achmed, 1974; cited in: Rohs, 2016, p. 15). They define informal education as follows: "Informal education as used here is the lifelong process by which every person acquires and accumulates knowledge, skills, attitudes and insights from daily experiences and exposure to the environment - at home, at work, at play; from the example and attitudes of family and friends; from travel, reading newspapers and books; or by listening to the radio or viewing films or television. Generally, informal education is unorganized and often unsystematic; yet it accounts fort the great bulk of any person's total lifetime learning including that of even a highly 'schooled' person".

The natural and routine character of situations that people experience on a daily basis means that they do not equate them with learning, although as it turned out in the second half of the twentieth century, it is from these that they draw the most knowledge. The results of the first empirical study of adult learning spaces, conducted by the Canadian researcher Allen Tough and published in his book "The Adult's Learning Project” (1971), showed that 80\% of one's knowledge comes 
from learning in the course of their everyday life. Mary Parker Follett, American specialist in management and organizational theory, already at the beginning of the twentieth century emphasized the educational role of local groups and networks (in the context of learning democratic behavior). She postulated creating stronger and closer links between life and learning: "The training for democracy can never cease while we exercise democracy. We older ones need it exactly as much as the younger ones. That education is a continuous process is a truism. It does not and with graduation day; it does not end when 'life' begins. Life and education must never be separated. We must have more life in our universities, more education in our life” (Follett, 1918, p. 369; cited in: Rohs, 2016, p. 9).

Informal learning owes its unprecedented popularity to the concept of lifelong learning, which defines this phenomenon as an individual and biographical continuum. It is no longer subject to negation or discussion, because educational episodes are scattered throughout human biography and located in multiple social circumstances (Field, 2003, p. 79). Dogmatic has become the thesis that individual learning is always of a social nature and is the result of one's participation in the world of practice, of dialogue with others, of implementing common tasks, resolving tensions, negotiating and renegotiating meanings (Malewski, 2010, pp. 118-119). The situated nature of learning, which constitutes its framework, points to categories such as: closeness, involvement, being present, participation. Learning does not happen in a vacuum; learning needs a specific space and a specific time.

Several centuries after Aristotle so many competing theories of learning have arisen that it is difficult to orient oneself within the diverse landscape. Behavioral, cognitive, constructivist, phenomenological, pragmatic, situation-oriented, actionoriented, and subject-oriented approaches all discuss learning. Nevertheless, they all emphasize that synonymous with learning is change: change in behavior, action, personality.

\section{DEFINITIONS OF INFORMAL LEARNING IN SELECTED EUROPEAN COUNTRIES}

As yet, no single, uniform definition of informal education/non-formal learning has been developed in Europe. An overview of current definitions of informal learning (Werquin, 2017, pp. 39-64) in selected European countries - specifically Greece, Bulgaria, Italy, Spain, the Netherlands, England, Wales, Denmark, Norway, Germany, and France - confirms the view that most of them do not yet have 
an official definition of informal learning. Various national organizations and scientific communities use their own definitions, which are by and large similar to the definitions popularized by international organizations: the European Commission (including Cedefop), OECD, and UNESCO. For example, here is a definition provided by the European Commission (2000, p. 8): "Informal learning is a natural accompaniment to everyday life. Unlike formal and non-formal learning, informal learning is not necessarily intentional learning and so may well not be recognised even by individuals themselves as contributing to their knowledge and skills".

Even countries in which education is centralized to a high degree (e.g., France) make no explicit effort to introduce a uniform definition of informal learning (Werquin, 2017, p. 54). Meanwhile, the development of such a uniform definition is a necessity at the European level, for instance because of the shaping of the European area of higher education, whose aim is, inter alia, facilitating the recognition of qualifications and periods of study. Activities to develop procedures for validating the outcomes of learning, currently undertaken in individual countries, are to increase the transparency of qualifications and competences held by Europeans. This also stems from the desiderata of international organizations, including the European Union in relation to its member countries. In Poland, a definition was adopted that refers to the ones presented both by Cedefop (2008) and by Eurostat (2006): “The acquisition of knowledge, skills, and social competences in the course of various activities outside the organized forms of learning” (IBE, 2013, p. 19).

The definitions used at the European level are primarily criticized for the following reasons:

1. The are not always precise in the sense that the wording may be ambiguous (mostly, usually, may...);

2. They overlap on many levels (intentionality...);

3. They leave some issues widely open (e.g., intentionality of the learning, leading to a qualification, inclusion of random learning), and do not well prepare the ground for the future of research and policymaking (Werguin, 2017, p. 58).

\section{AREAS OF RESEARCH ON INFORMAL LEARNING}

In this part of the article, we will briefly examine several areas of research on informal learning, without exhausting, of course, the entire spectrum of scientific explorations. We will refer to biographical research, informal learning in the world of work, and informal learning in social contexts, such as family and volunteer work. 


\section{BIOGRAPHICAL RESEARCH}

Polish andragogues, similarly to their counterparts around the world, became interested in informal learning as a result of European policy, which made it one of the areas of lifelong learning of its citizens. At the end of the twentieth century, Dzierżymir Jankowski (1999), published a high-profile book on self-education, defining it as "a process autonomously initiated and realized by an individual" (p. 13). The author does not question the external factors that inspire this process indirectly (e.g., symbolic culture, the organization of social life) and directly (counseling, resource availability, socio-moral support), but does nevertheless attribute the fundamental role to the activity of the individual. Another strong impulse for Polish researchers came in the form of a publication by Mieczysław Malewski (2010), which brought the Polish reader closer to the current international debate on informal learning and its theories (e.g., Peter Jarvis's existential learning theory, or Jean Lave and Etienne Wenger's situated learning theory), but above all signaled changing the paradigm from teaching to learning. Consequently, researchers became open to a new perspective, according to which learning is a continuous development, a permanent interpersonal dialogue, a gathering of experience and knowledge; it is a path to perfection which in each biography takes on a different, unique form. In addition, learning has been given a constitutive meaning in the context of shaping individual identities and the functioning of the individual in the present and the future (Brzezińska, 2006, p. 18). Reflection over one's own biography, being aware of one's beliefs, needs, and motives, allows one to understand "who one is" and to share meanings with other people (Brzezińska, 2006, p. 21). Referring to the leading role of the speaking subject, the narrator in the auto-educational process, Gaston Pineau (1983; cited in: Delory-Momberger, 2007, pp. 147-148) defined the methodology of biographical research as "the process of acquiring one's own educational power". The term "lifelong learning” reflects the relationship between biography, experience, learning, as well as the closeness of these concepts (Przybylska, 2014, p. 324). In connection with the shift toward one's learning in everyday life, Polish andragogy has seen a boom in biographical studies. A review of such periodicals as "Edukacja Dorosłych" [Adult Education] and "Rocznik Andragogiczny" [The Andragogical Yearbook], published by Akademickie Towarzystwo Andragogiczne [The Academic Andragogical Society], allows us to state that the biographical approach has dominated other areas of research on informal learning.

In German adult education, biographical studies are equally popular. Dieter Nittel (2018, p. 145) asserts that their hold over German andragogy has not weakened over the last 30 years, which is rather rare, because researchers' interests are 
usually subject to dynamic evolution. The author also notes that the biographical approach has further dominated the practice of adult education and the sphere of planning educational offers. Another matter is the fact that the achievements of German adult education in the field of biographical research are very rich. Initiated by Peter Alheit (1983), who conducted his research first in Bremen and then in Göttingen, it has gained numerous followers at almost all German universities (Nittel, 2018, p. 150). By way of examples, some of the biographical research that has enjoyed tremendous publicity includes studies among the shipyard workers in Rostock, born between 1955 and 1961, which has revealed various learning habits (Herzberg, 2004); research on the causes of functional illiteracy (Egloff, 1997); research on the relationship between identity building and education (Kade, 1989), and many others. It is worth adding that a strong impulse for the development of biographical research has come from ESREA (European Society for Research on the Education of Adults), which has organized numerous seminars and workshops for European biographical research scientists active in the field. Nittel (2018, p. 155) notes that biographical studies of adult education are most actively conducted in Poland, the Netherlands, Sweden, Austria, England, and the USA.

\section{RESEARCH ON INFORMAL LEARNING IN THE WORLD OF WORK}

The "twin" phenomena of work and learning (Becker, 2016, p. 226) are currently considered with increasing intensity through the prism of economics. Researchers are interested in categories such as cost, loss, price, revenue, profit, income, remuneration, profitability, premium. The entire collection of these elements deserves to be taken into account and, in practice, is (probably) more or less consciously analyzed by anyone engaged in work and learning, in order to ensure the profitability of one or the other. In other words, both working people and learners measure the economy of their activities, expressed through the relationship between the achieved results and incurred expenses. The turn of economics toward informal learning has been primarily stimulated by new concepts of work organization that resulted from the megatrends of modernity, such as internationalization and globalization, modern communication and information technologies, the digitalization of the world of work, its increasing character as a service industry, transformations in the sphere of values, as well as a subjectivization of work (Dehnbostel, 2016, p. 346). Learning at one's place of work, or, in other words, learning integrated into the work process, is in all likelihood beneficial from an economic perspective. In the era of growing expectations on the part of employees toward their professional work, such activities increase the attractiveness of work, contributing, among others, to a deepening bond between an employee and his or 
her workplace. This, in turn, may translate into increasing the company's chances in a competitive market. It is not surprising, therefore, that informal learning at work is intriguing not only to andragogy, but increasingly also to the economic sciences. Often, the close relationship between adult education and the economy, which has so far been expressed in particular through the requirement of providing employees with qualifications in line with the needs of the labor market, is enriched with a new meaning. At issue is the simultaneous improvement of the quality of work and learning as mutually interpenetrating processes that condition the development of individuals, enterprises, and national economies. It is undisputedly in the interest of businesses to create working conditions conducive to the improvement of employees' competences. Their intellectual, methodological, and personal capital can determine the success or failure in a competitive market. Hence the need for businesses to have the fullest possible knowledge about the learning processes available in the work environment, their conditions, and their barriers. In Polish pedagogy, learning at the workplace is primarily looked at by the pedagogues of work: Zygmunt Wiatrowski, Zdzisław Wołk, Ryszard Gerlach, Stefan M. Kwiatkowski, and many others. Among the educational functions of contemporary enterprises, Kwiatkowski (2017, p. 158) mentions didactic and educational, among others. The first "is linked with the creation for employees of conditions for systematic education, further training, and professional development”. While education and further training is located by the author within non-formal education (courses, training, academic classes) taking place in closed time periods, he includes vocational training as part of informal learning: "[...] improvement is a continuous process. It is learning during the course of work - in the process of implementing increasingly complex professional tasks". In turn, the educational function of the business includes, according to Kwiatkowski (2017, p. 158), "socioprofessional adaptation of school and university graduates undertaking work, as well as employees changing the nature of their work for various reasons - rank, specialization, and even occupation. Adaptation is not a single act. It is a kind of process, an interaction that occurs between and employee and his or her colleagues and, speaking more broadly, the enterprise”. The workplace as a learning environment is also the subject of a monograph by Magdalena Czubak-Koch (2014), titled "Learning in the Culture of the Workplace", which sees the world of work as a space for constructing various educational experiences. The author examines the world of work as a space of culture and social learning, revealing how an individual is entangled in the various aspects of his or her existence.

German researchers of workplace learning processes (Frieling \& Schäfer, 2017) seek, in particular, an answer to the question: How should the world of work 
be structured to foster learning on the part of individuals and teams of employees? Thus far, opportunities for optimizing the world of work in order to intensify learning integrated with work have been hardly recognized, but there are mentions of several factors that have a positive impact on this process. These include a friendly climate and affiliative relations in the workplace, employees having time for learning, the support of these processes by experts or auxiliary materials (e.g., scripts), and appropriate recognition and honoring of the readiness to learn and its results. Essentially, researchers emphasize organizational aspects that are conducive to informal learning processes in the workplace (Frieling \& Schäfer, 2017, pp. 469-482). Nevertheless, among the factors that support learning processes they also mention the complex nature of tasks (employees participate in all stages of production of a given product), autonomy (the ability of the employees to make decisions), diversity and changeability of requirements (homogeneity suppresses creativity), and interactivity (discussion, openness, exchange of experience and information). The researchers also closely observe the educational potential of teamwork. Research on teams of employees made up of people in different age groups indicates both their value and limitations. Longitudinal tests carried out by German psychologists of economics show the preponderance of negative factors over positive ones (Wegge, Roth, \& Schmidt, 2008). Other studies of the learning potential of age-diverse teams (Ries et al., 2013) suggest that the effectiveness of learning processes increases when team members are able to respect older people, are sensitive to manifestations of age discrimination, and have competence in the field of age management. In addition, the effectiveness of these teams is fostered by the multidimensionality and the complexity of tasks. An example of this are teams of engineers or scientists formed by specialists of various ages that are able to achieve impressive results thanks to, among others, consolidating the different competences of representatives of different generations (Ries et al., 2013). As regards economics, from the point of view of the employee, one of the undoubtedly important advantages of learning integrated with work is the limitation of time and of potential costs of participating in formal and non-formal educational offers. For the employer, in turn, the advantage lies in the possibility of reducing organizational and financial expenses associated with employee training. However, it should be noted that informal learning processes at the workplace remain a phenomenon closely related to the educational activity of employees developed in the area of formal and non-formal education. At the same time, these processes point to certain limitations of learning processes taking place in institutional contexts that do not favor the development of certain competences as much as learning directly at the workplace does. Here, at issue in 
particular are competences necessary to modernize and optimize work processes, the competence of teamwork and networking, reflective action in the work environment, or the self-directed learning process (Dehnbostel, 2016, p. 346).

\section{INFORMAL LEARNING IN VARIOUS SOCIAL CONTEXTS}

Polish pedagogy (including sociology, psychology, anthropology, and many other scientific disciplines) abounds in publications devoted to the family. We will not, therefore, refer to its characteristics or discuss the various research perspectives represented in this body of work. Nevertheless, it is worth emphasizing that, even in andragogy interested in adult learning processes, the family has been viewed first and foremost as a place of primary socialization of a child, hence attention has been focused on the educational competences of adult family members. Although the situation is currently changing, the primary theme remains the educational role of the parents. In her review of Polish family studies, Anna Kotlarska-Michalska (2015) concludes that in the twenty-first century new threads appear in the reflection on the family with regard to material and family roles, division of labor, absentee fatherhood, communication between family members, or the delayed entry into parenting roles. An increasing number of researchers are also looking at the relations between the different generations represented in the family.

Parents as educators of the young generation also occupy a leading position in scientific and research reflections in German adult education (Schmidt-Wenzel, 2016, p. 286). However, the family as a place of informal learning is gaining interest. Similarly to Polish andragogical discourse, attention of our Western neighbor is also drawn to issues related to the transmission of the familial cultural and social capital (Brake \& Büchner, 2011; Ecarius, 2010), to transgenerational learning in the family (Schmidt-Hertha, 2014; Franz, 2009), to the development of competences among adult family members (Friebe, Schmidt-Hertha, \& Tippelt, 2014), and learning activities of the elderly (Iller, 2018; Iller \& Wienberg, 2011). For example, research into the digital, social, linguistic, or mathematical competences of people over 65 confirms that the family is a place of informal education for all its members, without exception: older people living in multigenerational families have higher competences than people living alone or with a partner of similar age (Friebe, Schmidt-Hertha, \& Tippelt, 2014).

German literature also touches on issues that are absent or treated only marginally in Polish publications, e.g., the functioning of a migrant family in a foreign culture (Hamburger \& Hummrich, 2007), "rainbow families” formed by homo-, bi-, and transsexual people (Faulstic \& Zeuner, 1999; Rupp, 2009), or the literacy of all family members (Nickel, 2016). 
Volunteering is another area of informal learning to which both Polish and German researchers devote a lot of attention. Polish authors, describing the comprehensive conditions of volunteering, indicate the possibility of developing the competences of young and, increasingly, older people through voluntary work (Kromolicka, 2005; Krakowiak, Modlińska, \& Binnebesel, 2008; Kanios, 2010; Stawiarska, 2011; Krakowiak, 2012). Anna Janowicz (2013, p. 170) states that "volunteering is also a special pedagogical tool in relation to the so-called difficult students with learning difficulties, usually also burdened with family problems. [...] For them, volunteering is a lesson in responsibility, building trust and proper relationships with other people. It shows them what real emotions and life values are. It is a chance to rebuild their self-esteem and rediscover their place in school, in the local environment, in society”. Janowicz (2013, p. 165) also offers benefits of volunteering for older people: "Another argument for the fact that volunteering for people in post-productive age is a worthwhile investment is its activating and integrating character. It can contribute to the integration of older people in local communities. It is a response to the seniors' concern that they are not needed in old age. Teaching pro-social attitudes to retirees and pensioners, as well as showing them that their experience and presence are still valuable to others, improve their quality of life and functioning”. The above quotes seem to be characteristic of the Polish discourse on volunteering. The authors try to convince their readers of the positive qualities of volunteering, which is not surprising considering the low involvement of Poles in social activities. Compared to the rest of Europe, we are failing badly (CBOS, 2016).

In Germany, as Wiebken Düx and Erich Saas write (2016, p. 366), researchers became interested in volunteering in the mid-1980s. Initially, their focus was on the specifics of volunteering that differentiate it from other forms of human activity, such as professional or home work. Subsequently, researchers saw in it a special environment for learning and socialization, one conducive to the development of social, personal, cultural, and other skills useful in the labor market (Buhl \& Kuhn, 2005; Rauschenbach, Düx, \& Sass, 2006; cited in: Düx \& Saas, 2016, p. 366). Dozens of research projects confirm the great importance of volunteering for the development of human competences, the majority of which concern young people (e.g., Fischer, 2001; Richter, Jung, \& Riekmann, 2007). As a result of the empirical research, it was recognized that, besides school and the family, volunteering constitutes the third pillar affecting active participation and social integration of young people (Reinders, 2005). Among the features of volunteering particularly beneficial for learning processes, researchers emphasize voluntary participation, having a community with a group of peers, the possibility of shaping some section 
of social reality, participation in social events, taking responsibility, learning by doing, and the support of adult, experienced volunteers and employees (Düx et al., 2008). In contrast, the findings of empirical research on informal learning in the context of volunteering among people of middle and older age are much more modest (Resch \& Strümpel, 2009, p. 83; cited in: Thalhammer \& Schmidt-Hertha, 2018, p. 956). Still, research projects implemented thus far suggest that people learn through volunteering regardless of their age. Even prior to deciding whether to become socially involved, they observe, analyze, and examine what kinds of activities suit them best, and through voluntary work they gain valuable experience and develop a number of relevant competences (Thalhammer \& SchmidtHertha, 2018, p. 957).

In general, German researchers of learning processes in volunteering (Klemm, 2008; Picot, 2012; Düx \& Sass, 2016) express concerns about the future of volunteering among the youth. These concerns stem from the fact that young people are increasingly burdened with school commitments and learning duties. Moreover, free time is increasingly appropriated by modern technologies.

\section{CONCLUSION}

The topics sketched in the present article refer only superficially to the informal learning areas of adolescents and adults, and barely mark a certain section of Polish and German andragogical research out of its ever richer spectrum. A complete presentation of research conducted in this field is impossible in one article. Informal learning has fascinated science to such an extent that hundreds of publications and projects are being published every year. Just to signal a few additional research areas, there is informal learning at school, in vocational and university education, during leisure time; informal learning from philosophical, psychological, and sociological perspectives; informal learning in museums, cultural centers, through sports, and the use of modern information and communication technologies. Increasingly, researchers are also contemplating ways of validating the effects of informal learning, scientific methods for studying learning processes that occur in everyday life, in human micro-worlds, and a statistical measurement of the population size of learners learning informally. So far, science has no tools that would help develop a comprehensive and reliable definition of informal learning. Some researchers question whether the distinction between formal and nonformal education is altogether justified, since knowledge acquired in one area of human functioning permeates all others (Colley, Hodkinson \& Malcolm, 2003). 
Rather, this division seems to hinder scientific analysis and does not contribute to a deeper understanding of the phenomenon of human learning.

\section{References}

Alheit, P. (1983). Alltagsleben. Zur Bedeutung eines gesellschaftlichen „Restphänomens”. Frankfurt am Main: Campus.

Andresen, L., Boud, D., \& Cohen, R. (2000). Experience-Based Learning. In: G. Foley (Ed.), Understanding Adult Education and Training (pp. 225-239). Sydney: Allen \& Unwin.

Becker, M. (2016). Informelles Lernen aus wirtschaftswissenschaftlicher Perspektive. In: M. Rohs (Ed.), Handbuch Informelles Lernen (pp. 225-256). Wiesbaden: Springer VS.

Brake, A., \& Büchner, P. (2011). Bildungsort Familie. Habitusgenese im Netzwerk gelebter Familienbeziehungen. In: A. Lange \& M. Xyländer (Eds.), Bildungswelt Familie. Theoretische Rahmung, empirische Befunde und disziplinäre Perspektiven (pp. 142-166). Weinheim: Juventa.

Brzezińska, A. I. (2006). Kultura - wychowanie - tożsamość. In: K. Chmielewska (Ed.), Edukacja humanistyczna w nowym stuleciu. Rola humanistyki w kształtowaniu świata wartości i postaw młodych Polaków (pp. 16-25). Kraków: Zakład Narodowy im. Ossolińskich, Instytut Badań Literackich PAN.

Buhl, M., \& Kuhn, H.P. (2005). Erweiterte Handlungsräume im Jugendalter: Identitätsentwicklung im Bereich gesellschaftlichen Engagements. In: B.H. Schuster, H.P. Kuhn \& H. Uhlendorf (Eds.), Entwicklung in sozialen Beziehungen - Heranwachsende in ihrer Auseinandersetzung mit Familie, Freunden und Gesellschaft (pp. 217-237). Stuttgart: Lucius u. Lucius.

CBOS (2016). Potencjał społecznikowski oraz zaangażowanie w pracę społecznq. Komunikat z badań nr 15. Retrieved from: https://www.cbos.pl/SPISKOM.POL/2016/K_015_16.PDF [access date: 20.06.2018].

Cedefop (2008). Terminology of European Education and Training Policy: A Selection of 100 Key Terms. Luxembourg: Office for Official Publications of the European Communities.

Colley, H., Hodkinson, P., \& Malcolm, J. (2003). Informality and Formality in Learning: A Report for the Learning and Skills Research Centre. London: Learning and Skills Research Centre.

Coombs, P.H. (1968). The World Education Crisis. A System Analysis. London, Toronto: Oxford University Press.

Coombs, P.H., \& Achmed, M. (1974). Attacking Rural Poverty: How Non-Formal Education Can Help. Baltimore, London: World Bank.

Czubak-Koch, M. (2014). Uczenie się w kulturze miejsca pracy. Wrocław: Wydawnictwo Naukowe Dolnośląskiej Szkoły Wyższej.

Dehnbostel, P. (2016). Informelles Lernen in der betrieblichen Bildungsarbeit. In: M. Rohs (Ed.), Handbuch Informelles Lernen (pp. 343-364). Wiesbaden: Springer VS.

Delory-Momberger, Ch. (2007). Biographisches Lernen. In: M. Göhlich, Ch. Wulf, \& J. Zirfas (Eds.), Pädagogische Theorien des Lernens (pp. 142-152). Weinheim, Basel: Beltz Juventa.

Düx, W., \& Sass, E. (2016). Informelles Lernen im freiwilligen Engagement. In: M. Rohs (Ed.), Handbuch Informelles Lernen (pp. 365-377). Wiesbaden: Springer VS. 
Düx, W., Prein, G., Sass, E., \& Tully, C.J. (2008). Kompetenzerwerb im freiwilligen Engagement. Eine empirische Studie zum informellen Lernen im Jugendalter. Wiesbaden: VS Verlag für Sozialwissenschaften.

Ecarius, J. (2010). Familieninteraktion - Identitätsbildung und Kultur - soziale Reproduktion. In: H.R. Müller, J. Ecarius, \& H. Herzberg (Eds.), Familie, Generation und Bildung - Beiträge zur Erkundung eines informellen Lernfeldes (pp. 17-32). Opladen: Barbara Budrich.

Egloff, B. (1997). Biographische Muster „funktionaler Analphabeten”. Eine biographieanalytische Studie zu Entstehungsbedingungen und Bewältigungsstrategien von „funktionalem Analphabetismus”. Frankfurt am Main: DIE.

European Commission (2000). A Memorandum on Lifelong Learning. Commission Staff Working Paper SEC(2000). Retrieved from: http://arhiv.acs.si/dokumenti/Memorandum_on_ Lifelong_Learning.pdf [access date: 22.06.2018].

Eurostat (2006). Classification of Learning Activities - Manual. Luxembourg: Office for Official Publications of the European Communities. Retrieved from: http://www.uis.unesco. org/StatisticalCapacityBuilding/Workshop\%20Documents/Education\%20 [access date: 4.4.2018].

Faulstich, P., \& Zeuner, C. (1999). Erwachsenenbildung-eine handlungsorientierte Einführung in Theorie, Didaktik und Adressaten. Weinheim: Juventa.

Field, J. (2003). Badania nad całożyciowym uczeniem się dorosłych: tendencje i perspektywy w świecie anglojęzycznym. Teraźniejszość - Człowiek - Edukacja, 1, pp. 63-80.

Fischer, C. (2001). „Das gehört jetzt irgendwie zu mir”. Mobilisierung von Jugendlichen aus den neuen Bundesländern zum Engagement in einem Umweltverband. Eine explorative Studie am Beispiel der Bundjugend. Dissertation. TU Chemnitz.

Follett, M.P. (1918). The New State: Group Organization, the Solution for Popular Government. New York: Longmann, Green and Co.

Franz, J. (2009). Intergenerationelles Lernen ermöglichen. Orientierungen zum Lernen der Generationen in der Erwachsenenbildung. Bielefeld: Bertelsmann.

Friebe, J., Schmidt-Hertha, B., \& Tippelt, R. (Eds). (2014). Kompetenzen im höheren Lebensalter. Ergebnisse der Studie „Competencies in Later Life” (CiLL). Bielefeld: W. Bertelsmann Verlag.

Frieling, E., \& Schäfer, E. (2017). Arbeitsgestaltung für informelles Lernen. In: M. Rohs (Ed.), Handbuch Informelles Lernen (pp. 469-482). Wiesbaden: Springer VS.

Hamburger, F., \& Hummrich, M. (2007). Familie und Migration. In: J. Ecarius (Ed.), Handbuch Familie (pp. 112-134). Wiesbaden: VS Verlag.

Herzberg, H. (2004). Biographie und Lernhabitus. Eine Studie im Rostocker Werftarbeitermilieu. Frankfurt am Main-New York: Campus.

IBE (2013). Sławiński, S. (Ed.), Słownik podstawowych terminów dotyczqcych krajowego systemu kwalifikacji. Warszawa: IBE.

Iller, C. (2018). Höheres Erwachsenenalter und Bildung. In: R. Tippelt, \& B. Schmidt-Hertha (Eds.), Handbuch Bildungsforschung (pp. 845-860). Wiesbaden: Springer VS.

Iller, C., \& Wienberg, J. (2011). Learning in Social Relationships: A Contribution to Contented Ageing? International Journal of Education and Ageing, 2(1), pp. 41-54.

Jankowski, D. (1999). Autoedukacja wyzwaniem współczesności. Toruń: Wydawnictwo Adam Marszałek. 
Janowicz, A. (2013). Edukacja i koordynacja elementem włączania do wolontariatu sąsiedzkiego i parafialnego w społeczności lokalnej. In: T. Biernat, \& J.A. Malinowski (Eds.), Edukacja a włączenie społeczne. Konteksty socjalne i pedagogiczne (pp. 163-179). Toruń: Wydawnictwo Edukacyjne „Akapit”.

Kade, J. (1989). Erwachsenenbildung und Identität. Weinheim: Beltz.

Kanios, A. (2010). Społeczne kompetencje studentów do pracy w wolontariacie. Lublin: Wydawnictwo Uniwersytetu Marii Curie-Skłodowskiej.

Klemm, K. (2008). Bildungszeit. Vom Umgang mit einem knappen Gut. In: H. Zeiher, \& S. Schroeder (Eds.), Schulzeiten, Lernzeiten, Lebenszeiten. Pädagogische Konsequenzen und zeitpolitische Perspektiven schulischer Zeitordnungen (pp. 21-30). Weinheim: Juventa.

Kotlarska-Michalska, A. (2015). Obrazy życia rodzinnego z perspektywy półwiecza badań nad rodziną polską. In: I. Taranowicz, \& S. Grotowska (Eds.), Rodzina wobec wyzwań współczesności (pp. 27-56). Wrocław: Oficyna Wydawnicza ARBORETUM.

Krakowiak, P. (2012). Wolontariat w opiece u kresu życia: geneza, rozwój, funkcjonowanie, możliwości optymalizacji i integracji: ku syntezie socjopedagogicznej. Toruń: Wydawnictwo Naukowe Uniwersytetu Mikołaja Kopernika.

Krakowiak, P., Modlińska, A., \& Binnebesel, J. (Eds.). (2008). Podręcznik koordynatora wolontariatu hospicyjnego. Gdańsk: „Via Medica”.

Kromolicka, B. (Ed.). (2005). Wolontariat w obszarze humanistycznych wyzwań opiekuńczych. Toruń: Wydawnictwo Edukacyjne „Akapit”.

Kwiatkowski, S.M. (2017). Edukacyjne funkcje współczesnych przedsiębiorstw. Edukacja Ustawiczna Dorosłych, 4(99), pp. 157-166.

Malewski, M. (2010). Od nauczania do uczenia się. O paradygmatycznej zmianie w andragogice. Wrocław: Wydawnictwo Naukowe Dolnośląskiej Szkoły Wyższej.

Nickel, S. (2016). Family Literacy. Familienorientiertes Lernen im Kontext von Grundbildung. In: C. Löffler, \& J. Korfkamp (Eds.), Handbuch zur Alphabetisierung und Grundbildung Erwachsener (pp. 201-213). Münster, New York: Waxmann.

Nittel, D. (2018). Biographietheoretische Ansätze in der Erwachsenenbildung. In: R. Tippelt, \& A. v. Hippel (Eds.), Handbuch Erwachsenenbildung/ Weiterbildung. Vol. 1 (pp. 145-159). Wiesbaden: Springer VS.

Picot, S. (2012). Jugend in der Zivilgesellschaft. Freiwilliges Engagement Jugendlicher im Wandel. Gütersloh: Bertelsmann.

Pineau, G. (1983). Produire sa vie: autoformation et autobiographie. Montreal: Éditions coopératives Albert Saint-Martin.

Przybylska, E. (2014). Analfabetyzm funkcjonalny dorosłych jako problem społeczny, egzystencjalny i pedagogiczny. Toruń: Wydawnictwo Naukowe Uniwersytetu Mikołaja Kopernika.

Rauschenbach, T., Düx, W., \& Sass, E. (Eds.). (2006). Informelles Lernen im Jugendalter. Vernachlässigte Dimensionen der Bildungsdebatte. Weinheim, München: Juventa.

Reinders, H. (2005). Jugend. Werte. Zukunft. Wertvorstellungen, Zukunftsperspektiven und soziales Engagement im Jugendalter. Stuttgart: Landesstiftung Baden-Württemberg.

Resch, K., \& Strümpel, C. (2009). Informelles Lernen und Möglichkeiten freiwilligen Engagements im Alter - Sichtbarkeit, Motive und Rahmenbedingungen. bildungsforschung, 
6(1), pp. 79-96. Retrieved from: https://ojs4.uni-tuebingen.de/ojs/index.php/bildungsforschung/article/view/87/89 [access date: 20.06.2018].

Ries, B.C., Diestel, S., Shemla, M., Liebermann, S.C., Jungmann, F., Wegge, J., \& Schmidt, K.H. (2013). Age Diversity and Team Effectiveness. In: C. Schlick, E. Frieling, \& J. Wegge (Eds.), Age-Differentiated Work Systems (pp. 89-118). Berlin: Springer.

Richter, H., Jung, M., \& Riekmann, W. (2007). Jugendverbandsarbeit in der Großstadt. Perspektiven für Mitgliedschaft und Ehrenamt am Beispiel der Jugendfeuerwehr Hamburg. Hamburg: Eigenverlag Jugendfeuerwehr.

Rohs, M. (2016). Genese informellen Lernens. In: M. Rohs (Ed.), Handbuch Informelles Lernen (pp. 3-38). Wiesbaden: Springer VS.

Rupp, M. (2009). Die Lebenssituation von Kindern in gleichgeschlechtlichen Lebenspartnerschaften. Köln: Bundesanzeiger Verlag.

Schmidt-Hertha, B. (2014). Kompetenzerwerb und Lernen im Alter. Bielefeld: W. Bertelsmann Verlag.

Schmidt-Wenzel, A. (2016). Familie als informelles Lern- und Bildungsfeld. In: M. Rohs (Ed.), Handbuch Informelles Lernen (pp. 285-302). Wiesbaden: Springer VS.

Stawiarska, P. (2011). Wolontariat hospicyjny: perspektywa interdyscyplinarna. Warszawa: Difin.

Thalhammer, V., \& Schmidt-Hertha, B. (2018). Bildungsforschung zum informellen Lernen. In: R. Tippelt, \& B. Schmidt-Hertha (Eds.), Handbuch Bildungsforschung. Vol. 2 (pp. 947-966). Wiesbaden: Springer VS.

Tough, A. (1971). The Adult's Learning Project: A Fresh Approach to Theory and Practice in Adult Learning. Toronto: The Ontario Institute for Studies in Education.

Wegge, J., Roth, C., \& Schmidt, K.H. (2008). Eine aktuelle Bilanz der Vor- und Nachteile altersgemischter Teamarbeit. Wirtschaftspsychologie, 10(3), pp. 30-43.

Werquin, P. (2017). International Perspectives on the Definition of Informal Learning. In: M. Rohs (Ed.), Handbuch Informelles Lernen (pp. 39-64). Wiesbaden: Springer VS. 